Jennens, M. G. (1954). J. gen. Microbiol. 10, 127-129.

\title{
The Effect of Desiccation on Antigenic Structure
}

\author{
By MARY G. JENNENS \\ National Collection of Type Cultures, Colindale Avenue, London, N.W. 9
}

\begin{abstract}
SUMMARY: Two different organisms were dried in normal rabbit serum and in the presence of specific antibody. Reconstitution of the dried products showed that the presence of antibody did not affect the viability, agglutinability or the absorptive capacity of the bacteria.
\end{abstract}

Drying by sublimation has become a routine method of preserving bacterial cultures. Although criticism is seldom made in print, several workers who do not themselves dry their cultures suggest that in the drying process there may be a selective killing, or change of unidentified characters, particularly those of an antigenic nature.

In the last four years more than a thousand strains of bacteria have been dried in the National Collection of Type Cultures, and the cultural characters before drying compared with those after drying. The morphological and biochemical characters have never shown any significant change, but some strains have shown an apparent increase in rough-surfaced colonial forms after drying. Most of the strains were dried in filtered horse serum, and it was thought that occasionally a culture might be suspended and dried in the presence of antibody in the so-called normal serum. It seemed unlikely that drying in the presence of antibody would have any effect on the organism, though subsequent growth in the reconstituted serum might increase the proportion of R-forms. Experiments were planned to furnish evidence on this point and cultures were dried in the presence of high titre antibody.

\section{MATERIALS AND METHODS}

Strains. A paracolon organism (NCTC 8535, M.R.C. Standards Laboratory strain 3915) with the $\alpha$-antigen (Stamp \& Stone, 1944), and a strain of a salmonella species (NCTC 6759) with the antigenic formula 1, 3, 19:i $\leftrightarrow$ z, were used.

Antisera. The antisera, prepared in the M.R.C. Standards Laboratory were kindly supplied by Lt-Col. H. J. Bensted. The $\alpha$-antiserum had a titre of $1 / 20,000$. The salmonella 0 serum had titres of $1 / 1000$ and $1 / 5000$ in two successive bleedings.

Drying of cultures. Strains were grown on Lemco agar and the cells suspended in normal rabbit serum or rabbit antiserum. Volumes of $0.1 \mathrm{ml}$. were dried in an Edwards's model 3T spin-freeze drying plant, followed by secondary drying for $c .18 \mathrm{hr}$. with $\mathrm{P}_{2} \mathrm{O}_{5}$ as desiccant. Ampoules were sealed in vacuo and stored at room temperature in the dark.

Viable counts. Dried material was reconstituted in broth and normally dilutions were made in broth. Counts were made by the Miles \& Misra method (1938). 
Agglutination tests. Readings of $\alpha$-antibody were made after $18 \mathrm{hr}$. at $50^{\circ}$, of 0 antibody after $18 \mathrm{hr}$. at $37^{\circ}$.

\section{RESULTS}

\section{Effect of antibody on viable count}

The paracolon organism was suspended in: (1) normal rabbit serum; (2) rabbit antiserum diluted with normal rabbit serum so that the $\alpha$-agglutinin titre was 1/1000; (3) rabbit antiserum with an $\alpha$-agglutinin titre of $1 / 20,000$; (4) broths containing 1 and $\mathbf{7 \cdot 5} \%$ glucose. Viable counts made before drying and at intervals after drying are shown in Table 1 . The differences between the three products dried in serum were not great, and probably not greater than the experimental error. In glucose broth counts were greater both before and after drying, and there was no significant difference between the counts in the two concentrations of glucose. Viable counts are not necessarily counts of single cells; specific antibody may increase the size of bacterial clumps and so diminish the number of colonies. An ampoule of suspension dried in $\alpha$-antibody was reconstituted in distilled water, and duplicate dilutions were made in broth (containing $\mathbf{0 . 5} \% \mathrm{NaCl}$ ) or in distilled water. The absence of electrolyte was expected to inhibit clumping due to a specific antigen-antibody reaction, but in fact the experiment showed a slightly higher count in the series of dilutions made in broth. This experiment indicated that specific antibody was not clumping the bacteria and so artificially decreasing the viable count.

\section{Table 1. Viable counts of paracolon organisms} dried in normal serum and in antiserum

\begin{tabular}{|c|c|c|c|c|c|c|}
\hline \multirow[b]{2}{*}{ Suspending fluid } & \multirow{2}{*}{$\begin{array}{l}\text { Before } \\
\text { drying }\end{array}$} & \multicolumn{5}{|c|}{ Interval (months) after drying } \\
\hline & & $\mathbf{0}$ & 1 & $\mathbf{3}$ & 6 & 12 \\
\hline & \multicolumn{6}{|c|}{ Viable count $\times 10^{8} / \mathrm{ml}$} \\
\hline Normal serum & 450 & 30 & $9 \cdot 5$ & 20 & 10 & 10 \\
\hline$\alpha$-Antibody $1 / 1000$ & $\mathbf{5 5}$ & 45 & 25 & 15 & 10 & 11 \\
\hline$\alpha$-Antibody $1 / 20,000$ & 90 & 15 & 2 & $6 \cdot 5$ & 3 & $\mathbf{3}$ \\
\hline $1 \%$ Glucose broth & 1400 & ND & 650 & $\mathbf{5 5 0}$ & 400 & 900 \\
\hline $7 \cdot 5 \%$ Glucose broth & 2200 & 1050 & 950 & 1100 & 750 & 750 \\
\hline
\end{tabular}

\section{Effect of antibody on agglutinability}

Suspensions were prepared from cultures (1) not dried, (2) dried in normal serum, (3) dried in antibody; each was tested for agglutinability by specific antibody. Paracolon 3915 suspensions were made from cultures that had been dried for 6 months; the salmonella culture was tested soon after drying. The agglutinability of the cultures (Table 2 ) was not significantly affected by drying and comparable suspensions did not show a difference greater than one tube.

After revival from the dried state the salmonella strain was subcultured rapidly five times and then tested for agglutinability and absorptive capacity (see below); neither property differed from that of the strain before it was dried. 
Table 2. Agglutinability of suspensions made from cultures (a) always grown on media, (b) dried in normal serum, (c) dried in specific antibody

\begin{tabular}{llr} 
Suspension from culture & $\begin{array}{c}\text { Paracolon } \\
\text { Agglutination titre }\end{array}$ \\
\cline { 2 - 2 } Not dried & $1 / 10,000$ & $1 / 5,120$ \\
Dried in normal serum & $1 / 10,000$ & $1 / 5,120$ \\
Dried in antibody & $1 / 20,000$ & $1 / 2,560$
\end{tabular}

Effect of antibody on absorptive capacity

Bulk suspensions were made of paracolon 3915 which had been dried in normal rabbit serum and in rabbit antiserum with an $\alpha$-antibody titre of $1 / 20,000$. Both suspensions had an absorptiometer opacity equivalent to $95 \times 10^{8} \mathrm{organisms} / \mathrm{ml}$. The centrifuged deposit of $10 \mathrm{ml}$. of each suspension was rubbed up in $5 \mathrm{ml}$. of $\alpha$-antiserum diluted 1/15. The mixtures were incubated for $2 \mathrm{hr}$. at $37^{\circ}$, centrifuged, and the supernatant fluids tested for residual antibody. Absorption was incomplete, each supernatant giving a trace reaction at $1 / 16$ of the diluted serum. Centrifuged deposits of $5 \mathrm{ml}$. suspension were added to the incompletely absorbed supernatants, and these removed the residual agglutinins.

Absorption of 1, 3, 19 salmonella antiserum by suspensions from cultures that had or had not been dried was similarly carried out in two stages, after which absorption was complete.

\section{DISCUSSION}

These experiments did not produce any evidence that the act of drying bacteria in the presence of specific antibody had any significant effect on viability, agglutinability or absorptive capacity. Thus fears that antigenic changes might occur in the drying process, or that a selective killing of sensitive (and antigenically different) cells might change the antigenic pattern of the bacterial population, appear to be groundless.

The antigens studied were of two kinds, a labile and a stable antigen. Neither type of antigen seemed to be damaged by the drying process. It had been assumed by Cowan (1952) that bacteria dried in the presence of specific antibody might be so sensitized that on reconstitution they would agglutinate and so diminish the number of colonies which developed in the viable count, but experiments to show this effect were unsuccessful. Even when bacteria were dried in antiserum with an agglutinating titre of $1 / 20,000$, the decrease in the number of countable colonies was well within the experimental error.

\section{REFERENCES}

Cowan, S. T. (1952). In Freezing and Drying, p. 163. London: Institute of Biology. MrLes, A. A. \& Misra, S. S. (1938). The estimation of the bactericidal power of the blood. J. Hyg., Camb. 38, 732.

Stamp, Lord \& Stone, D. M. (1944). An agglutinogen common to certain strains of lactose and non-lactose-fermenting coliform bacilli. J. Hyg., Camb. 43, 266. 